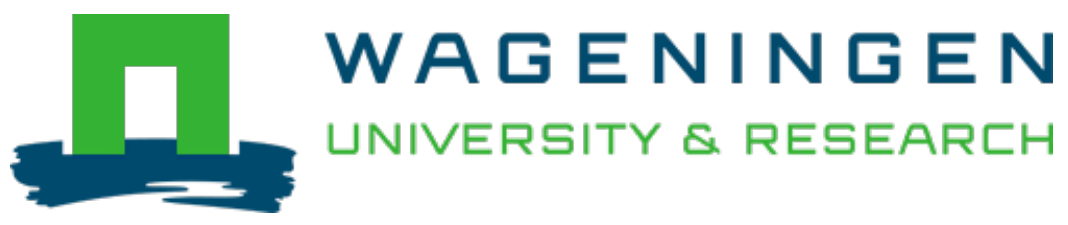

\title{
Microbiological changes in mawè during natural fermentation
}

World Journal of Microbiology and Biotechnology

Hounhouigan, D.J.; Nout, M.J.R.; Nago, C.M.; Houben, J.H.; Rombouts, F.M.

https://doi.org/10.1007/BF00144462

This publication is made publicly available in the institutional repository of Wageningen University and Research, under the terms of article $25 \mathrm{fa}$ of the Dutch Copyright Act, also known as the Amendment Taverne. This has been done with explicit consent by the author.

Article $25 \mathrm{fa}$ states that the author of a short scientific work funded either wholly or partially by Dutch public funds is entitled to make that work publicly available for no consideration following a reasonable period of time after the work was first published, provided that clear reference is made to the source of the first publication of the work.

This publication is distributed under The Association of Universities in the Netherlands (VSNU) 'Article $25 \mathrm{fa}$ implementation' project. In this project research outputs of researchers employed by Dutch Universities that comply with the legal requirements of Article $25 \mathrm{fa}$ of the Dutch Copyright Act are distributed online and free of cost or other barriers in institutional repositories. Research outputs are distributed six months after their first online publication in the original published version and with proper attribution to the source of the original publication.

You are permitted to download and use the publication for personal purposes. All rights remain with the author(s) and / or copyright owner(s) of this work. Any use of the publication or parts of it other than authorised under article $25 \mathrm{fa}$ of the Dutch Copyright act is prohibited. Wageningen University \& Research and the author(s) of this publication shall not be held responsible or liable for any damages resulting from your (re)use of this publication.

For questions regarding the public availability of this publication please contact openscience.library@wur.nl 


\title{
Microbiological changes in mawè during natural fermentation
}

\author{
D.J. Hounhouigan, ${ }^{\star}$ M.J.R. Nout, C.M. Nago, J.H. Houben and F.M. Rombouts
}

Lactic acid bacteria increased from $3.2 \times 10^{6}$ and $1.6 \times 10^{7}$ c.f.u./g (wet wt) to $2 \times 10^{9}$ and $1.6 \times 10^{9}$ c.f.u./g after 12 to $24 \mathrm{~h}$ of fermentation of home-produced mawè (a dough produced from dehulled maize) and commercial mawè, respectively. In commercial mawè, the yeast count increased from $1.3 \times 10^{5}$ to $2.5 \times 10^{7}$ c.f.u./g after $48 \mathrm{~h}$ of fermentation before decreasing, whereas in the home-produced mawè it increased from $2.5 \times 10^{4}$ to $3.2 \times 10^{7}$ c.f.u./g after $72 \mathrm{~h}$ of fermentation; the dominant yeasts were mainly Candida krusei, although C. kefyr, C. glabrata and Saccharomyces cerevisiae were also present. Enterobacteriaceae counts increased slightly during the initial stage of the fermentation, but decreased below the detection level after 24 to $48 \mathrm{~h}$. Enterobacter cloacae was mostly found in commercial mawè and Escherichia coli mostly in homeproduced mawè.

Key words: Enterobacteriaceae, fermentation, lactic acid bacteria, maize, mawè, yeast.

In Africa, most of the traditional cereal-based fermented foods are processed by natural fermentations. In most cases the microorganisms involved in these fermentations are lactic acid bacteria and yeasts (Akinrele 1970; Christian 1970; Nout 1980; Fields et al. 1981; Mbugua 1984; Odunfa \& Adeyele 1985; Adegoke \& Babalola 1988). These and Enterobacteriaceae have also been detected in home-produced and commercial mawè (Hounhouigan et al. 1993a), reaching about $10^{9}, 10^{7}$ and $10^{4}$ c.f.u./g of mawè, respectively. Natural fermentation of mawè results in a product of variable quality. Development of controlled fermentation is necessary for the manufacture of a product of consistent quality. This requires knowledge of the microorganisms involved and their impact on the product. In a previous paper we characterized the lactic acid bacteria (LAB) isolated from mawè (Hounhouigan et al. 1993b). The present report deals with the microbiological changes in mawe during natural fermentation and identifies the predominant yeasts and enterobacteria involved.

D.J. Hounhouigan and C.M. Nago are with the Universite Nationale du Bénin, Faculté des Sciences Agronomiques, Département de Nutrition et de Sciences Alimentaires, BP 526, Cotonou, Benin; fax: 229313559 . M.J.R. Nout and F.M. Rombouts are with the Agricultural University, Department of Food Science, Bomenweg 2, 6703 HD Wageningen, The Netherlands. J.H. Houben is with Utrecht University. Department of the Science of Foods of Animal Origin, Yalelaan 2, 3508 TD Utrecht, The Netherlands. "Corresponding author.

(1) 1994 Rapid Communications of Oxford Ltd

\section{Materials and Methods}

\section{Sample Preparation}

Home-produced and commercial mawè were produced in a local milling shop, as described earlier, using maize cultivar Sékou 85 (10 kg for each process) provided by the International Institute of Tropical Agriculture, Benin (I Iounhouigan et al. 1993c). The dough ( $46 \%$ moisture content, wet wt basis) resulting from each process was divided equally between six plastic buckets, kneaded, covered with a polyethylene sheet and allowed to ferment spontaneously for $72 \mathrm{~h}$ at room temperature $\left(28\right.$ to $\left.32^{\circ} \mathrm{C}\right)$. Duplicate experiments were carried out for each process.

Isolation and Purification of Microorganisms

Samples $(10 \mathrm{~g})$ of mawè from each process were taken after 0 (kneading stage), 6, 12, 24, 48 and $72 \mathrm{~h}$ of fermentation, and each immediately homogenized in a stomacher (Lab-blender 400; Seward Medical, London UK) with $90 \mathrm{ml}$ of sterile $0.5 \%(\mathrm{w} / \mathrm{v})$ peptone, containing $0.85 \%(\mathrm{w} / \mathrm{v}) \mathrm{NaCl}, \mathrm{pH} 7.0 \pm 0.2$, and decimally diluted. Total aerobic mesophilic bacteria, LAB, lactobacilli, yeasts and Enterobacteriaceae were enumerated by the pour method as described previously (Hounhouigan et al. 1993a). Yeasts were randomly picked from plates at each of the sampling times and purified by streaking on yeast extract/glucose/agar plates (Oxoid CM 545) and incubating at $25^{\circ} \mathrm{C}$ for 3 to 5 days. After microscopic examination, purified cultures were grown on slants of the same medium and stored at $5^{\circ} \mathrm{C}$. Randomly selected colonies of Enterobacteriaceae were isolated from plates at different time intervals between 0 and $24 \mathrm{~h}$, purified on Tryptone/soya/agar plates (Oxoid CM 131) at $37^{\circ} \mathrm{C}$ for 18 to $24 \mathrm{~h}$ 
and identified approximately by Gram-staining and microscopical examination. Stock cultures were grown on the same medium and stored at $5^{\circ} \mathrm{C}$ for further identification.

\section{Identification Tests}

Yeast fermentation profiles were carried out on ATB 32C or ID $32 \mathrm{C}$ strips (API system S.A., Montalieu Vercieu, France). Preliminary identification was according to Lodder \& Kreger van Rij (1984) and the identity was confirmed by the Centraalbureau voor Schimmelcultures Yeast Division (Delft, The Netherlands). Identification of the Enterobacteriaceae was performed using the RapiD 20E system (API system S.A., Montalieu Vercieu, France).

Statistical Analysis

Samples from different processes and fermentation periods were statistically compared using analysis of variance (Snedecor \& Cochran 1989).

\section{Results and Discussion}

The microbial compositions of home-produced and commercial mawè are shown in Tables 1 and 2 , respectively. The numbers of total aerobic mesophilic bacteria and lactic acid bacteria (I.AB) were not significantly different between both types of mawè during the fermentation period, but the numbers of yeasts were significantly different $(P<0.05)$. High initial numbers of total aerobic mesophilic bacteria, LAB and yeasts were probably due to microorganisms in the commercial mill, acting as an inoculant during wet milling (Wacher et al. 1993). The vessels and the sieves used during processing also probably contributed. The highest counts of aerobic mesophilic bacteria and LAB were obtained 12 and $24 \mathrm{~h}$ of fermentation. The yeast counts increased until $48 \mathrm{~h}$ in commercial mawè before decreasing, but continued increasing in the home-produced mawè. This supports our previous observation that home-produced mawè does not stabilize microbiologically even after $72 \mathrm{~h}$ of fermentation (Hounhouigan et al. 1993c).

Enterobacteriaceae showed a slight increase during the early stages of the fermentation, but decreased to below the detection level after 1 day in commercial mawè and 2 days in home-produced mawè.
The predominant lactic acid bacteria isolated from mawè have been identified (Hounhouigan et al. 1993b). Most of them $(89 \%)$ were obligate heterofermenters and included Lactobacillus fermentum (biotype cellobiosus), Lactob. fermentum or Lactob. reuteri and Lactob. brevis, all of which accounted for about $85 \%$ of the strains isolated. Other species identified were Lactob. curvatus, Lactob. confusus, Lactob. buchneri, Lactococcus lactis, Pediococcus pentosaceus, $\boldsymbol{P}$. acidilactici, Leuconostoc mesenteroides, Lactob. lactis and Lactob. salivarius.

The identity of the yeasts is shown in Table 3. They were dominated by Candida species, including C. krusei (mainly), C. kefyr and C. glabrutu. Succharomyces cerevisiae was also isolated.

Table 4 summarizes the identity of the Enterobacteriaceae. Six of the 10 strains from commercial mawè were identified as Enterobacter cloacae whereas 19 of the 20 strains from homeproduced mawè were identified as Escherichia coli. Other species identified included Klebsiella pneumoniae and Serratia odorifera, both from commercial mawè. Escherichia coli is generally considered to be an indicator of faecal contamination. The presence of Fs. coli in mazuè may be due to faecal contamination of the maize used and their relatively low number in the commercial mawè could be due to the extent of washing of the grits, which does not occur in the preparation of home-produced mawè.

$\mathrm{LAB}$, yeasts and Enterobacteriaceae grew together, at least during the 12 to $24 \mathrm{~h}$ fermentation period, contributing to the characteristics of the final product, probably by producing organic acids, ethanol, $\mathrm{CO}_{2}$ and other volatile flavour compounds. It had been suggested that microbial amylases play an important role in the production of fermentable sugars from maize immersed in water (Akinrele 1970). According to Nout (1980), the multiplication of Lactobacillus spp. in souring maize is favoured by the production of fermentable sugars from the auto-amylolysis of maize. Sugar (mostly glucose and maltose) concentrations increased from approx. $1.8 \%$ to $2.6 \%$ to approx. $3.0 \%$ to $4.3 \%(\mathrm{w} / \mathrm{w})$ in the commercial mawè in the first $24 \mathrm{~h}$ of fermentation and subsequently decreased (unpublished data). In addition, the development of LAB is stimulated by yeasts which provide soluble nitrogen compounds and other growth factors, e.g. the B-vitamins (Nout 1991). Yeast

\begin{tabular}{|c|c|c|c|c|c|c|}
\hline $\begin{array}{l}\text { Fermentation time } \\
\text { (h) }\end{array}$ & pH & $\begin{array}{c}\text { Total aerobic } \\
\text { mesophilic bacteria }\end{array}$ & $\begin{array}{l}\text { Lactic acid } \\
\text { bacteria }\end{array}$ & Lactobacilli & Yeasts & Enterobacteriaceae \\
\hline 0 & 6.25 & 6.5 & 6.5 & 6.3 & 4.4 & 2.5 \\
\hline 6 & 4.35 & 9.1 & 9.2 & 9.0 & 4.8 & 3.8 \\
\hline 12 & 4.02 & 9.1 & 9.2 & 9.1 & 4.9 & 3.2 \\
\hline 24 & 3.85 & 9.3 & 9.2 & 9.3 & 6.5 & 3.4 \\
\hline 48 & 3.75 & 9.0 & 9.1 & 9.1 & 7.3 & $<1.7$ \\
\hline 72 & 3.65 & 9.0 & 9.2 & 9.1 & 7.5 & $<1.7$ \\
\hline
\end{tabular}

"Values are means of two independent determinations. Replicates were within $11 \%$ of the mean for the $0 \mathrm{~h}$ samples and within $5 \%$ of the mean at the other time intervals. 
Table 2. Changes in the microblal counts $\left(\log _{10}\right.$ c.f.u $/ g$ wet wt) during fermentation of commercial mawe.*

\begin{tabular}{lcccccc}
\hline $\begin{array}{l}\text { Fermentation time } \\
\text { (h) }\end{array}$ & $\mathbf{p H}$ & $\begin{array}{c}\text { Total aerobic } \\
\text { mesophilic bacteria }\end{array}$ & $\begin{array}{c}\text { Lactic acid } \\
\text { bacteria }\end{array}$ & Lactobacilli & Yeasts & Enterobacteriaceae \\
0 & 6.13 & 7.2 & 7.2 & 7.2 & 5.1 & 3.2 \\
6 & 4.12 & 9.0 & 9.0 & 8.9 & 5.2 & 3.6 \\
12 & 3.83 & 9.2 & 9.2 & 9.0 & 6.2 & 3.2 \\
24 & 3.63 & 9.1 & 9.2 & 9.2 & 7.2 & $<1.7$ \\
48 & 3.51 & 8.8 & 9.0 & 8.9 & 7.4 & $<1.7$ \\
72 & 3.47 & 8.5 & 8.8 & 8.7 & 6.5 & $<1.7$ \\
\hline
\end{tabular}

*Values are means of two independent determinations. Replicates were within $11 \%$ of the mean for the $0 \mathrm{~h}$ samples and within $5 \%$ at the other time intervals.

Table 3. Identification of the yeasts isolated from mawe.

No. of isolates from:

\begin{tabular}{lcc} 
Specles & Home-produced mawe & Commercial mawè \\
Candida krusei & 17 & 14 \\
Candida kefyr & 5 & 2 \\
Candida glabrata & 3 & 2 \\
Saccharomyces & 2 & 10 \\
$\quad$ cerevisiae & & 28 \\
Totals & 27 & \\
\hline
\end{tabular}

Table 4. Species of Enterobacteriacese isolated from mawe.

No. of isolates from:

\begin{tabular}{lcc} 
Specles & Home-produced mawè & Commercial mawè \\
Enterobacter cloacae & 1 & 6 \\
Escherichia coli & 19 & 1 \\
Klebsiella pneumoniae & - & 1 \\
Serratia odorifera & - & 1 \\
Not identified & - & 1 \\
Totals & 20 & 10 \\
\hline
\end{tabular}

metabolites, e.g. $\mathrm{CO}_{2}$, pyruvate, propionate, acetate and succinate, have been shown to stimulate lactobacilli in kefir (Leroi \& Pidoux 1993). On the other hand, the acidic environment created by lactobacilli is favourable for yeast growth (Wood 1981). This association of LAB and yeasts has been noticed in several cereal foods. Candida krusei and Sa. cerevisiae were found with LAB during the fermentation of busaa, a Kenyan opaque maize-millet beer (Nout 1980). Odunfa \& Adcyele (1985) found Lactobacillus spp. and Lactococcus lactis together with C. krusei and Debaryomyces hansenii during the fermentation of ogi-baba, a West African fermented sorghum gruel. Adegoke \& Babalola (1988) found Sa. cerevisiae together with Lactob. fermentum, Lactob. brevis and Enterococcus faecalis in the fermentation of ogi, while Akinrele (1970) found that corynebacteria, Sa. cerevisiae, Enterob. cloacae and Lactob. plantarum were prominent in ogi. More recently, Halm et al.
(1993) found obligately heterofermentative lactobacilli closely related to Lactob. fermentum and Lactob. reuteri, in association with Candida spp. and Saccharomyces spp., in fermented maize dough from Ghana.

It is unclear if Enterobacteriaceae function in the mawè fermentation. As the acidic environment created by LAB is not favourable for their growth, their number decreases strongly after the first day of fermentation. Similar antimicrobial effects have been found in other lactic fermentations and the inhibitors have been suggested to be antibiotic substances (Mensah et al. 1991; Mbugua \& Njenga 1992). A negative aspect is that coliform species have been reported to be responsible for offflavours and flavour instability in Kenyan uji (Mbugua 1982). Taking into consideration the very low numbers of Enterobacteriaceae in mawè, it seems unlikely that they are responsible for the remarkable off-flavours, noticed particularly in the home-produced version. These off-flavours, combined with the undesirable sour taste which develops beyond $24 \mathrm{~h}$ fermentation due to a high titratable acidity (Hounhouigan et al. 1993c), make home-produced mawè less desirable than commercial mawè in urban areas.

\section{Acknowledgements}

Facilities and technical assistance, provided by the DutchBeninese University Co-operation Programme, by the European Community (through CIRAD-CA/Laboratoire de Technologie des Céréales, Montpellier) and by the International Foundation for Science to one of us (DJH), are gratefully acknowledged.

\section{References}

Adegoke, G.O. \& Babalola, A.K. 1988 Characteristics of microorganisms of importance in the fermentation of fufu and ogi, two Nigerian foods. Journal of Applied Bacteriology 65, 449-453.

Akinrele I.A. 1970 Fermentation studies on maize during the preparation of a traditional African starch-cake food. Journal of the Science of Food and Agriculture 21, 619-625. 
Christian, W.F.K. 1970 Lactic acid bacteria in fermenting maize dough. Ghana Journal of Science 10, 22-28.

Fields, M.L., Hamad M., \& Smith, D.K. 1981 Natural lactic acid fermentation of corn meal. Journal of Food Science 46, 900-902.

Halm M., Lillie A., Sørensen A.K \& Jakobsen M. 1993 Microbiological and aromatic characteristics of fermented maize doughs for kenkey production in Ghana. International Journal of Food Microbiology 19, 135-143.

Hounhouigan, D.J., Nout, M.J.R., Nago, C.M. Houben, J.H. \& Rombouts, F.M. 1993a Composition and microbiological and physical attributes of mawè, a fermented maize dough from Bénin. International Journal of Food Science and Technology 28, 513-517.

Hounhouigan, D.J., Nout, M.J.R., Nago, C.M. Houben, J.H. \& Rombouts, F.M. 1993b Characterization and frequency distribution of species of lactic acid bacteria involved in the processing of mawè, a fermented maize dough from Bénin. International Journal of Food Microbiology 18, 279-287.

Hounhouigan, D.J., Nout, M.J.R., Nago, C.M. Houben, J.H. \& Rombouts, F.M. 1993c Changes in the physico-chemical properties of maize during natural fermentation of mawè. Journal of Cereal Science 17, 291-300.

Leroi, F. \& Pidoux, M. 1993 Characterization of interactions between Lactobacillus hilgardii and Saccharomyces florentinus isolated from sugary kefir grains. Journal of Applied Bacteriology 74, 54-60.

Lodder, J. \& Kreger van Rij, N.J.W. (eds) 1984 The Yeasts. A Taxonomic Study, 3rd edn. Amsterdam: Elsevier Science.

Mbugua, S.K. 1982 Microbiological and biochemical aspects of uji (an East African sour cereal porridge) fermentation, and its enhancement through application of lactic acid bacteria. Dissertation Abstracts International 42, 3178.
Mbugua, S.K. 1984 Isolation and characterization of lactic acid bacteria during the traditional fermentation of uji. East African Agricultural and Forestry Journal 50, 36-43.

Mbugua, S.K. \& Njenga, J. 1992 The antimicrobial activity of fermented uji. Ecology of Food and Nutrition 28, 191-198.

Mensah, P., Tomkins, A.M., Drasar, B.S., \& Harrison, T.J. 1991 Antimicrobial effect of fermented Ghanaian maize dough. Journal of Applied Bacteriology 70, 203-210.

Nout, M.J.R. 1980 Microbiological aspects of the traditional manufacture of busaa, a Kenyan opaque maize beer. Chemie Mikrobiologie Technologie der Lebensmittel 6, 137-142.

Nout, M.J.R. 1991 Ecology of accelerated natural lactic fermentation of sorghum-based infant food formulas. International Journal of Food Microbiology 12, 217-224.

Odunfa, S.A. \& Adeyele, S. 1985 Microbiological changes during the traditional production of ogi-baba, a West African fermented sorghum gruel. Journal of Cereal Science 3, 173-180.

Snedecor, W.G. \& Cochran W.G. 1989 Statistical Methods, 8th edn. Ames: Iowa State University Press.

Wacher, C., Cañas A., Cook P.E., Barzana E. \& Owens J.D. 1993 Sources of microorganisms in pozol, a traditional Mexican fermented maize dough. World Journal of Microbiology and Biotechnology 9, 269-274.

Wood B.J.B. 1981 The yeast/Lactobacillus interaction. A study in stability. In Mixed Culture Fermentation, eds Bushell, M.E. \& Slater, J.H. pp. 137-150. London: Academic Press.

(Received in revised form 21 January 1994;

accepted 28 January 1994) 